\title{
Liability of local government units acting as contracting authorities in the light of the Public Finance Discipline Violation Liability Act
}

\author{
Odpowiedzialność jednostek samorządu \\ terytorialnego występujących $w$ roli \\ zamawiającego na tle ustawy o odpowiedzialności \\ za naruszenie dyscypliny finansów publicznych
}

\begin{abstract}
Local government units as entities of a public finance sector are obliged to apply provisions of the Public Procurement Law in cases in which the conditions specified in the content of this normative act are satisfied. This applies, in particular, when the value of the awarded public procurement contract exceeds the PLN equivalent of EUR 30,000. In the event of a violation of provisions of the Public Procurement Law by local government units acting as contracting authorities, the local government units shall not be directly liable. As a rule, the liable entity will be the head of the contracting authority, or members of the tender committee, or employees entrusted with performing specific tasks. The article
\end{abstract}


is devoted to the analysis of the liability of local government units acting as contracting authorities in the light of the Public Finance Discipline Violation Liability Act of 17 December 2004.

Keywords: public procurement; local government; liability; contracting authority.

Streszczenie. Jednostki samorządu terytorialnego jako jednostki sektora finansów publicznych obowiązane są do stosowania przepisów Prawa zamówień publicznych w przypadku spełnienia przesłanek wskazanych w treści tego aktu normatywnego. Dotyczy to w szczególności sytuacji, gdy wartość udzielanego zamówienia przekracza wyrażoną w złotych równowartość kwoty 30.000 euro. W przypadku naruszenia przez jednostki samorządu terytorialnego występujących $\mathrm{w}$ roli zamawiającego postanowień Prawa zamówień publicznych to nie j.s.t. poniesie bezpośrednią odpowiedzialność. Co do zasady podmiotem odpowiedzialnym będzie kierownik zamawiającego bądź członkowie komisji przetargowej lub pracownicy, którym powierzono wykonanie określonych czynności. Artykuł poświęcony jest analizie odpowiedzialności jednostek samorządu terytorialnego występujących w roli zamawiającego na tle ustawy z 17 grudnia $2004 \mathrm{r}$. o odpowiedzialności za naruszenie dyscypliny finansów publicznych.

Słowa kluczowe: zamówienia publiczne; samorząd terytorialny; odpowiedzialność; zamawiający.

\section{Introduction}

The principle of transparency of the financial management of local government units (LGUs) results both from the Constitution of the Republic of Poland ${ }^{1}$, the Act of 27 August 2009 on public finance ${ }^{2}$, and from the provisions of laws regulating the functioning of individual units ${ }^{3}$.

1 See for e.g. Article 61 of the Polish Constitution of 2 April 1997, Dz.U. [Polish Journal of Laws] of 1997, No 78, poz. [item] 483 with subsequent amendments.

2 See Article 33(1) of the Act of 27 August 2009 on public finance (consolidated text: Dz.U. of 2019, poz. 869), hereinafter: PFA.

3 In the case of a commune - Article 61(1) of the Act of 8 March 1990 on commune self-government, consolidated text: Dz.U. of 2019, poz. 506), hereinafter: CSGA, in the case of a poviat - Article 61 of the Act of 5 June 1998 on Poviat Self-Government (consolidated text: Dz.U. of 2019, poz. 511), hereinafter: PSGA, and in the case of 
This principle was formulated on the ius cogens ${ }^{4}$ principle. Its contents are socio-political demands. Conducting financial management on the basis of the budget provides information on the amount of public funds, the sources of obtaining them, as well as the directions and manner of using them. This allows to create conditions for social control over the management of public money resources, and thus it performs a preventive function. The principle of openness of the financial management of local government units also makes public fund administrators aware that their activities can be subject to social assessment, thus compelling them to spend these funds rationally ${ }^{5}$.

Transferring the above principle to this study, one should begin with the content of Article 3(1) of the Public Procurement Law ${ }^{6}$ which indicates the group of entities obliged to apply this normative act. It also includes LGUs which the legislator counted in among the entities of the public finance sector ${ }^{7}$. Article 3(1) of the Public Procurement Law, therefore, establishes the group of entities strictly obliged to apply provisions on public procurement, if the planned purchase is not excluded from the regulations of the Public Procurement Law pursuant to Article 4 or $4 \mathrm{~b}$ of the Public Procurement Law (PPL).

Owing to the fact that public procurement law sets out a particular manner of spending public funds, a compliance with it is highly important, above all, from the point of view of a public finance discipline. It is not without significance that the subject-matter of public procurement

a voivodship - Article 72 of the Act of 5 June 1998 on Voivodship Self-Government (consolidated text: Dz.U. of 2019, poz. 512), hereinafter: VSGA.

4 J. Glumińska-Pawlic, Komentarz do art. 61 ustawy o samorzqdzie gminnym [in:] B. Dolnicki (ed.) Ustawa o samorzqqdzie gminnym. Komentarz. 2 wyd., LEX No 587718911; J. Glumińska-Pawlic, Komentarz do art. 61 ustawy o samorzqdzie powiatowym [in:] B. Dolnicki, Ustawa o samorzqdzie powiatowym. Komentarz. 2 wyd., LEX No 587284497; J. Glumińska - Pawlic, Komentarz do art. 72 ustawy o samorzqdzie województwa [in:] B. Dolnicki (ed.), Ustawa o samorzq̨dzie województwa. Komentarz, LEX No 587334845.

5 T. Dębowska-Romanowska, Prawo budżetowe państwa i samorzq̨u terytorialnego [in:] W. Wójtowicz (ed.), Prawo finansowe, Warszawa 1999, pp. 113 et seq.

6 The Act of 29 January 2004 Public Procurement Law (consolidated text: Dz.U. of 2018, poz. 1986, with subsequent amendments), hereinafter: PPL.

7 See Article 3(1) point 1 of PPL in relation to Art. 9 point 2 of PFA. 
contracts often amounts to very high values. This is why public officials are prone to act contrary to the law, in particular to corrupt practices. Control of public procurement and conduct of procedures is, therefore, important for detecting improper activities resulting not only in violations of legal provisions, but also in negative public perception of public administration bodies.

Incorrect conduct of public procurement contract award procedure by LGUs acting as contracting authorities may result in liability under the Public Finance Discipline Violation Liability Act ${ }^{8}$. It should be emphasised that the said Act is not the only normative act determining the liability of LGUs. Such acts may also include the Penal Code ${ }^{9}$ and the Civil Code ${ }^{10}$.

However, owing to the wide scope of regulations with respect to the liability of LGUs which act as contracting authorities in connection with violation of the provisions of the Public Procurement Law, this publication is focused, in particular, on provisions of the Public Finance Discipline Violation Liability Act.

\section{The subjective scope of liability of LGUs acting as contracting authorities}

The Public Finance Discipline Violation Liability Act is one of the legal bases sanctioning LGUs as contracting authorities in the event of their violation of provisions of the Public Procurement Law. However, in contrast to the contracting authority's liability which is set out in the Public Procurement Law ${ }^{11}$, in the Public Finance Discipline Violation Liability

8 The Act of 17 December 2004 on liability for violation of public finance discipline (consolidated text: Dz.U. of 2019, poz. 1440), hereinafter: PFDVLA.

9 The Act of 6 June 1997 - the Polish Penal Code (consolidated text: Dz.U. of 2018, poz. 1600 with subsequent amendments), hereinafter referrred to as PC.

10 The Act of 23 April 1964 - Civil Code (consolidated text: Dz.U. of 2019, poz. 1145 with subsequent amendments).

11 The liability specified in the Act - Public Procurement Law is of formal nature. It is not assigned to a specific person, but to an individual whose liability under Article 199 of PPL has not been excluded (section VII of PPL does not apply to, among others, public finance sector entities and entities other than public finance sector entities of state organizational units without legal personality). A financial penalty is imposed by 
Act the liability is of a disciplinary and of personal in nature. This is because pursuant to Article 4 of the Public Finance Discipline Violation Liability Act (PFDVLA) a liability for a violation of public finance discipline, also in a field of public procurement, can be attributed only to a natural person and not to an organisational unit or legal entity.

When analysing the subjective scope of a liability of LGUs acting as contracting authorities, one should begin with Article 18 of the PPL. It provides for the liability of persons preparing and conducting on behalf of the contracting authority, including LGUs, the public procurement contract award procedure. In accordance with section (1) of this Article, the head of the contracting authority, which should be understood as a person or body, and which, in accordance with applicable regulations whether statutory or contractual, is authorised to manage the contracting authority, with the exception of proxies appointed by the contracting authority (Article 2(3) of PPL), is liable for a preparation and for conducting a public procurement contract award procedure. The head of the contracting authority may, therefore, depending on a specific case, be both a collegial body, e.g. a management board, and a specific natural person, e.g. the head of the office - in case of a commune it will be the commune head, mayor, city president; in case of a poviat it will be, in particular, a starost, and in case of the voivodship - the marshal. The head of the contracting authority defines an organization, a composition, a mode of work, and a scope of duties of the members of the tender committee in regulations of the tender committee or in a similar document, ensuring at the same time its efficiency (Article 21(3) of PPL). A person performing the function of the head of an entity should, therefore, be characterised by a high legal awareness and knowledge of regulations at a level higher than basic ${ }^{12}$.

way of an administrative decision by the President of the Public Procurement Office if the conditions listed in Article 200 of PPL are fulfilled.

12 See General Adjudicating Committee decision of 21 March 2011, BDF1/4900/12/13/11/507, LEX No 798192: “a person serving as the head of a unit should be characterised by high legal awareness and knowledge of legal regulations at a level higher than basic. This excludes the possibility of classifying the act committed by the head of the unit in the conditions of an excused error as to the law”. 
Other persons are also liable for the preparation and for the conduct of the public procurement contract award procedure to the extent that they have been entrusted with activities in the procedure and activities related to the preparation thereof. The term "other persons" includes primarily the contracting employee who has been entrusted by the head of the contracting authority with the performance of reserved tasks, a member of the tender committee, as well as a third party entrusted with the preparation and/or conduct of the public procurement contract award procedure ${ }^{13}$.

The institution of the tender committee (which is an auxiliary team for the head of the contracting authority) is not without significance when discussing the subjective scope of liability of LGUs acting as contracting authorities (Article 20 of PPL). Members of the tender committee are appointed and dismissed by the head of the contracting authority (Article 21(1) of PPL). It should be noted that the legislator does not specify the form in which the head of the contracting authority should appoint members of the tender committee. In practice, this is usually done in the form of a business order, a change of the scope of duties, or by issuing an ordinance, or a contract. It is important, therefore, to note that the selection of the thender committee made when appointing members of the tender committee should take into account their knowledge and competence. In the event that the contracting authority does not employ appropriate

13 Cf. Urząd Zamówień Publicznych, Kiedy zamawiajq̨cy może „wyręczyć się” osobq trzeciq? „Zamówienia Publiczne Doradca” 2006, No 7, pp. 30-31: “The provision [of Art. 18(2) of the Act of 2004 - the Public Procurement Law in the wording as of 26 June 2006] specifically provides only for the possibility of entrusting the employees of the contracting authority in writing with the performance of tasks reserved for the head of the contracting authority. However, this provision does not prohibit entrusting these tasks to persons who are not employees of the contracting authority in a situation where, in accordance with the authorization expressed in Article 15(2) of the Act, the contracting authority entrusts the preparation or preparation and conduct of a public procurement contract award procedure to its own organizational unit or a third party. As a consequence, these persons (persons to whom the head of the contracting authority has entrusted the performance of activities reserved for him as part of the procedure), are required to submit a declaration resulting from the ZP-11 form, corresponding to the content of Article 17(1) of PPL”. 
persons, it seems reasonable and purposeful, according to $\mathrm{W}$. Iwaniec, to appoint experts who are not employees of the contracting authority ${ }^{14}$.

It should also be emphasised that the tender committee is not authorised to perform legal actions. Its role is limited to the examination and evaluation of offers, examination of documents and making analysis of their content, making opinions, and the preparation of documents ${ }^{15}$. The tender committee is not an independent institution, because it does not take final decisions regarding, in particular, the results of the public procurement contract award procedure. The tender committee presents its proposals to the head of the contracting authority who accepts them or not, and his/her tender selections are considered binding decisions ${ }^{16}$.

It should be noted that the liability of LGUs acting as contracting authorities relates primarily to the person of the head of the contracting authority ${ }^{17}$. In the event of a violation of provisions on public procurement or a failure to fulfil obligations to which the head of the contracting authority was obliged by the legislator, he/she may be held liable under the Public Finance Discipline Violation Liability Act. This liability will be of of a direct and of a personal nature ${ }^{18}$. However, entrustment of activities

14 W. Iwaniec, Odpowiedzialność za nieprawidłowości w procesie przygotowania i udzielania zamówienia, „Zamówienia Publiczne Doradca” 2015, No 10, pp. 6-11.

15 Cf. D. Jagiełło, Kompetencje i zadania komisji przetargowej, „Zamówienia Publiczne Doradca” 2011, No 11, pp. 76-80.

16 Judgment of the National Chamber of Appeal of 5 December 2012, KIO 2577/12, LEX No 1252766. "The tender committee is an auxiliary team of the head of the contracting authority (Article 20 of the PPL), therefore its activities are not independent, but it presents only proposals that are accepted (or not) by the head of the contracting authority and it is his/her tender selections that are considered binding decisions." W. Iwaniec, Kryteria pozacenowe - bieżq̨ca praktyka - perspektywy, „Zamówienia Publiczne Doradca” 2019, No 3, pp. 1 -18; K. Padrak, Komisja przetargowa, „Zamówienia Publiczne Doradca” 2007, No 11, pp. 28-33; M. Meducki, Komisja przetargowa, „Zamówienia Publiczne Doradca” 2017, No 12, pp. 68-71.

17 Cf. M. Filipek, Dobór składu osobowego komisji przetargowej, „Zamówienia Publiczne Doradca” 2008, No 3, pp. 67-73; M. Ludziejewski, Najczęstsze błędy przy organizacji pracy komisji przetargowej, „Zamawiający” 2013, No 1, pp. 16-18.

18 See General Adjudicating Committee decision of 24 March 2011, BDF1/4900/107/117/10/3125, LEX No 852737; General Adjudicating Committee decision of 8 June 2009, BDF1/4900/30/28-29/RN-4-5/09/1113, LEX No 564437 and General Adjudicating Committee decision of 27 October 2008, BDF/GKO/4900/54/53/08/2091, LEX No 1725782. 
related to the preparation and/or the conducting of the public procurement contract award procedure to other persons, e.g. members of the tender committee by the head of the contracting authority, will not always result in an exclusion of his/her liability. The head of the contracting authority will also be personally liable if he/she conducts at least one step in the public procurement contract award procedure, e.g. if he/she takes part in a preparation of a project documentation ${ }^{19}$. Moreover, despite a proper entrustment of duties to the employee, the head of the contracting authority will be held directly liable when in fact these duties were performed by himself/herself ${ }^{20}$.

When entrusting the performance of activities related to the award of public procurement contracts, it should be remembered that although the legislator does not specify the form in which it should take place, the appropriate one appears to be in writing. In addition, it would be desirable for the employee to confirm in writing that he/she has accepted his/her duties and liabilities ${ }^{21}$. Furthermore, it is justified that the head of the contracting authority in the act of appointing the tender committee should carefully define the scope of duties of its individual members, so that in case of any irregularities, a member of the tender committee will be held liable ${ }^{22}$.

19 See General Adjudicating Committee decision of 22 February 2010, BDF1/4900/87/89/09/3148, LEX No 794045: “Article 17(4) of the Public Finance Discipline Violation Liability Act, when establishing an independent premise for liability, proof of the performance of activities (even one) in the public procurement procedure is at the same time required".

20 See decision of General Adjudicating Committee of 10 October 2013, BDF1/4900/70/74/13/RWPD-53271, LEX No 1506437 and decision of the General Adjudicating Committee of 1 July 2010, BDF1/4900/50/57/10/1381, LEX No 794499.

21 R. Pruszkowski, Zakres odpowiedzialności kierownika zamawiajqcego oraz innych osób uczestniczq̨cych w postępowaniu, cz. 1, „Zamówienia Publiczne Doradca” 2015, No 12, pp. 12-18.

22 See decision of General Adjudicating Committee of 10 September 2012, BDF1/4900/62/62/RN-10/ 12/1661, LEX No 1225183; Regional Accounting Chamber's decision of 22 December 2009, 0965-DB/125/09, LEX No 602891; General Adjudicating Committee decision of 23 March 2009, BDF1/4900/8/8/09/272, LEX No 1725541 . 


\section{The objective scope of liability of LGUs acting as contracting authorities}

Turning to the objective scope of a liability of LGUs acting as contracting authorities under the Public Finance Discipline Violation Liability Act, firstly it should be noted that the legislator included in Article 17 of PFDVLA a much broader and a more detailed catalogue of acts that may result in sanctions imposed on the contracting authority, than it did in the Public Procurement Law (cf. Article 200 of PPL). According to the adjudicating panel of the Supreme Court (SC) presented in the judgment of 13 January 2004 "the justification for a detailed normalisation of irregularities related to public procurement and qualifying them as a violation of public finance discipline results from the objectives of public procurement law, which expose public interest and eliminate corruption-generating situations"23.

The goal of the public procurement system is primarily the rational spending of public funds, counteracting corruption and ensuring equal treatment of entities applying for a public procurement contract award ${ }^{24}$.

Pursuant to Article 17 of PFDVLA, a violation of public finance discipline in the scope of public procurement consists of acts and omissions which are not in accordance with the provisions of the Public Procurement Law, and which include:

1. a description of an object of the public procurement contract in a manner that could hamper fair competition;

2. a determination of the value of the public procurement contract or a part thereof, if it affected an obligation to apply provisions of the Public Procurement Law or the application of public procurement provisions of a lower value;

3. a specification of participation conditions in the public procurement contract award procedure or evidence required from contractors in

23 Judgment of the Supreme Court of 13 January 2004, V CK 97/03, OSNC 2005/2, item 34

24 See also: decision of General Adjudicating Committee of 13 February 2003, DF/GKO/Odw.-134/170-171/2002, LEX No 80068. 
a manner unrelated or disproportionate to the object of the public procurement contract;

4. a determination of the tender evaluation criteria;

5. a failure to transfer for publication in the Official Journal of the European Union or a failure to publish in the Public Procurement Bulletin the public procurement notice, an establishment of a qualifying system of contractors notice, a notice on rectification, changes, or additional information regarding such notices or the contract award notice;

6. a failure to publish the Terms of Reference on the website;

7. a merge of public procurement contracts or dividing one contract into separate public procurement contracts, in order to avoid applying the provisions on public procurement;

8. a failure to notify the President of the Public Procurement Office of the initiation of the public procurement contract award procedure;

9. an award of a public procurement contract to a contractor who has not been selected in a manner specified in provisions of the Public Procurement Law;

10. an award of a public procurement contract in violation of provisions of the Public Procurement Law regarding the conditions for using public procurement contract award procedures: negotiations without notice, single-source procurement or price inquiry;

11. a conclusion of a framework contract without conducting the procedure in a manner specified in the Public Procurement Law;

12. a conclusion of a framework agreement in violation of provisions of the Public Procurement Law regarding the conditions for using the negotiations without notice procedure or the single-source procurement procedure;

13. a violation of provisions on public procurement in a different manner than described above, if it affected the outcome of the public procurement contract award procedure or a conclusion of the framework contract, respectively, unless no public procurement contract was awarded or framework contract concluded;

14. a conclusion of a framework agreement in a manner that could distort competition; 
15. a conclusion of a public procurement contract or a framework contract: a. without a written form,

b. for a longer period than specified in the Public Procurement Law or for an indefinite period, except for cases permitted by the provisions of the Public Procurement Law,

c. before the decision is announced by the National Chamber of Appeal, in violation of the provisions on public procurement;

16. an annulment of the public procurement contract award procedure in violation with provisions of the Public Procurement Law;

17. a failure to submit a declaration of a lack of grounds for exclusion from the public procurement contract award procedure or other declarations which may have an impact on the result of the procedure by the head of the contracting authority, a member of the tender committee, and other persons performing activities in this procedure on the part of the contracting authority;

18. a failure to exclude from the public procurement contract award procedure a person subject to exclusion therefrom pursuant to the provisions of the Public Procurement Law;

19. an amendment to the public procurement contract or the framework contract in violation of provisions on public procurement;

20. an award of a public procurement contract on the basis of a framework contract with a significant amendment to the terms of the award of the public procurement as specified in the framework contract;

The aforementioned provision penalises certain activities related to the preparation and/or a conduct of the procedure in a manner inconsistent with provisions on public procurement. The irregularity itself is already a criminal act, i.e. an act or omission contrary to the Public Procurement Law. Therefore, the liability arising from the public finance discipline is borne by the person committing this irregularity ${ }^{25}$. The substantive basis for liability for the torts referred to in Article 17 of PFDVLA are in particular the following provisions: Article 29, 32, 40, Article 62(2), Article

25 See General Adjudicating Committee decision of 7 November 2013, BDF1/4900/4900/56-59-60/13-RWPD-60460, LEX No 1728857. 
67(2), Article 91, Articl 93, and Article 95 of PPL, which are considered to be particularly significant from the point of view of public finances.

A faulty performance of an activity related to the preparation and/or a conduct of a public procurement contract award procedure is, first and foremost, harmful to principles of fair competition, openness, impartiality, and objectivity. According to M. Winiarz the public finance discipline includes a violation of the principle of fair competition only to the extent of the description of the object of the public procurement contract and the specification of the participation conditions in the procedure ${ }^{26}$. Some representatives of the doctrine believe that the requirement of impartiality is only one of the guarantees of maintaining fair competition and equality of contractors $^{27}$. It should be noted, however, that the legislator clearly distinguished the principle of fair competition from other principles, as well as the obligation to award a public procurement contract to the contractor whose tender was chosen as the most advantageous ${ }^{28}$.

When analysing case law regarding violations of Article 17 of PFDVLA it is impossible not to notice that the most common acts committed by the contracting authority are the description of the object of the public procurement contract in a manner that hampers fair competition ${ }^{29}$ and an introduction of amendments to the contract in violation of provisions on public procurement ${ }^{30}$. It seems that one of the problems in this case is in a correct understanding of "fair competition". The issue arose owing to the lack of a legal definition of the term "fair competition".

26 M. Winiarz, Odpowiedzialność za udzielanie zamówień publicznych w podsektorze samorzq̨dowym, „Finanse Komunalne” 2007, No 9, pp. 32-45.

27 Cf. J. Pieróg, Prawo zamówień publicznych. Komentarz, Warszawa 2012, p. 70.

28 M. Winiarz, Naruszenie zasady bezstronności w postępowaniu o udzielenie zamówienia publicznego jako naruszenie dyscypliny finansów publicznych, „Finanse Komunalne" 2015, No 10, pp. 54-63.

29 See judgment of the Voivodeship Administrative Court in Warsaw of 21 November 2012, V SA/Wa1487/12, LEX No 1338625, General Adjudicating Committee decision of 20 September 2007, DF/GKO-4900-38/42/07/1725, LexPolonica No 2124008, General Adjudicating Committee decision of 25 February 2013, BDF1/4900/4/5/13/54, LEX No 1526658.

30 See General Adjudicating Committee decision of 25 February 2016, BDF1.4800.145.2015, LEX No 2094418, General Adjudicating Committee decision of 16 January 2014, 4010/30/2013, LEX No 1551310. 
The Supreme Administrative Court in its judgment of 13 March $2013^{31}$ took the position that "the decoding of the legal norm contained in Article 17(1) point 3 of PFDVLA in the wording of 29 January 2010 requires a departure from the linguistic interpretation, because the meaning of the analysed provision is not unequivocal either in terms of the concept of «the object or conditions of public procurement», or the concept of fair competition rules or the manner of violating them. This fact alone determines the uselessness of the logical and linguistic interpretation. Although the term «fair competition» is an indeterminate phrase, there is no doubt that not only are agreements violating competition rules contrary to its essence, but also actions which the legislator (national or EU) describes as violating such rules, and are considered to be acts of unfair competition”.

The determination of the point in time when a possible liability is borne is not without a significance when discussing the contracting authority's liability in the light of Article 17(1) of PFDVLA. This problem was addressed by the General Adjudicating Committee which in its judgment of 8 September $2011^{32}$ stated that only acts that exist at the latest when the public procurement contract is awarded may be subject to liability for violation of Article 17(1) of PFDVLA. Therefore, these are acts committed before the award of the public procurement contract, i.e. before the conclusion of the contract or at the latest when the contract was concluded.

Attention should also be drawn to the content of Article 17(1)(a) of PFDVLA which contains a catalogue of circumstances excluding the unlawful conduct listed in section 1 . First of all, an act or an omission indicated in it will not constitute a violation of the public finance discipline if it has been corrected in a way which ensures a compliance of a given activity and a course of procedure with the provisions on public procurement. The second circumstance excluding unlawfulness is the lack of an effect of an unlawful conduct. If no public procurement contract preceded

31 Judgment of the Supreme Administrative Court of 13 March 2013, II GSK 2160/11, LEX No 1340119.

32 General Adjudicating Committee decision of 8 September 2011, BDF1/4900/54/60/ 11/1704, LEX No 1027288. 
by the procedure affected by errors specified in Article 17(1) of PFDVLA was awarded, then no spending took place. Thus, it is pointless to enforce a liability for a violation of public finance discipline ${ }^{33}$.

The condition for attributing liability under the Public Finance Discipline Violation Liability Act is finding fault in the act or omission of the person liable for applying the provisions on public procurement ${ }^{34}$. This guilt may be both intentional and unintentional. Pursuant to the decision of the General Adjudicating Committee (GAC) of 29 January 2009, BDF/GKO/4900/87/74/RN-16/08/848 ${ }^{35}$ “[...] in order to speak of guilt, it should be attributed to the accused. GAC would like to emphasise that the key to attributing guilt is the ability to indicate the correct pattern of behaviour to the accused, and therefore it must result from the proven circumstances that at the time the act was committed, alternative conduct that would not violate the law and which would not constitute violation of public finance discipline was possible. If it can be proved that in the given circumstances the accused had no other possibility of conduct, then despite the objective establishment of committing an unlawful act, no guilt can be assigned". The indicated position of the General Adjudicating Committee is identical to the previous judgment of the Supreme Administrative Court of 8 December 1999, III SA 363-364/99 36 according to which "the intention of a specific action cannot be attributed to the perpetrator, if other action would not be possible or legally permissible". Therefore, the limiting point of liability under the Public Finance Discipline Violation Liability Act is proving culpability on the part of the perpetra-

33 L. Lipiec-Warzecha, Komentarz do art. 17 [in:] L. Lipiec-Warzecha, Odpowiedzialność za naruszenie dyscypliny finansów publicznych. Komentarz, LEX No 587281187.

34 So also: General Adjudicating Committee decision of 14 March 2016, BDF1.4800.176.2015, LEX No 2094398, R. Pruszkowski, Przesłanki i praktyczne skutki naruszenia dyscypliny finansów publicznych $w$ zamówieniach publicznych, „Zamówienia Publiczne Doradca” 2009, No 9, pp. 14-27.

35 General Adjudicating Committee decision of 29 January 2009, BDF/GKO/4900/ 87/74/RN-16/08/848, LexPolonica No 2430502.

36 Judgment of the Supreme Administrative Court of 8 December 1999, III SA 363364/99, “Orzecznictwo Naczelnego Sądu Administracyjnego" (ONSA) 2001, No 1, item 25 . 
tor, as it is insufficient to indicate only a formal violation of the law ${ }^{37}$. Despite the fact that the subjective and the objective aspects of liability for a violation of public finance discipline have been established, liability will not be attributed when the conditions referred to in Article 78(1) point 1-8 of PFDVLA will be met.

In the event of a violation by the contracting authority (as defined in Article 3(1) point 1, 2 and 5 of the PPL) of the provisions on public procurement in accordance with Article 31(2) of PFDVLA the contracting authority may be subject to a penalty of: an admonition, a reprimand, a financial penalty in the amount of 0.25 to three times the monthly remuneration of the person liable for the violation of public finance discipline calculated as remuneration for the holiday leave due in the year in which the violation occurred, and a ban on performing functions related to the disposal of public funds for a period of one to five years.

The type of a punishment depends on the degree of harmfulness of the violation of the public finance discipline ${ }^{38}$. Its determination takes into account a gravity of violated obligations, a manner and circumstances of their breach, and its effects ${ }^{39}$. If the contracting authority does not apply the public procurement regulations at all, despite the statutory obligation, such action should be considered as a severely punishable act and constituting a significant violation of the principle of fair competition ${ }^{40}$.

The penalty for violating public finance discipline is left to a committee members' discretion. The principle of discretion in imposing penalties by a committee is a derivative of a guarantee of an independence of adjudicating committees' members. It means that no one has the right to impose any pressure upon the committee. According to the position of the General Adjudicating Committee expressed in the decision of 12 October

37 See: General Adjudicating Committee decision of 23 November 2006, DF/GKO-490083/103/06/2564, LexPolonica No 2214653.

38 See: General Adjudicating Committee decision of 14 July 2011, BDF1/4900/55/61/ 11/1729, LEX No 1027284.

39 See also: General Adjudicating Committee decision of 22 February 2016, BDF1.4800.153.2015, LEX No 2094414 and General Adjudicating Committee decision of 24 October 2013, BDF1/4900/48/53/13/RWPD-49748, LEX No 1506442.

40 General Adjudicating Committee decision of 3 December 2015, BDF1.4800.56.2015, LEX No 2094390. 
2006, DF/GKO-4900-68/85-86/06/2058 ${ }^{41}$ "the adjudicating authority shall impose a penalty at its own discretion. It is a principle from which the law does not provide exceptions". It should be emphasised that a free discretion in imposing a penalty does not mean voluntariness in this regard. The committee's discretion in terms of imposing a penalty means that its members are not bound by orders, instructions, ordinances, or circulars. It is the obligation of the adjudicating committee to make a comprehensive assessment of the evidence and the circumstances of the violation of the public finance discipline ${ }^{42}$.

\section{Conclusions}

LGUs acting as contracting authorities are obliged to be meticulous and diligent in preparing and in conducting the public procurement contract award procedure. It should be emphasised, however, that LGUs will not themselves be liable for a violation of the provisions of the Public Procurement Law, because their liability was excluded by the legislator pursuant to Article 199 of the PPL. However, this does not mean that an improper award of public procurement contracts will result in impunity. In case of a breach of provisions of the Public Procurement Law by LGUs acting as the contracting authorities the liability will be, in principle, borne by the head of the contracting authority, or by members of the tender committee, or by employees entrusted with performing specific activities in the preparation and conduct of the procedure.

It should be noted that incurring liability under the Public Finance Discipline Violation Liability Act does not exclude a liability under other legal provisions. If a given act simultaneously fulfils the conditions of several normative acts, there may be a convergence of provisions on liability. This means that the contracting authority violating the provisions of the Public Procurement Law may be held liable not only under provisions

41 General Adjudicating Committee decision of 12 October 2006, DF/GKO-4900-68/8586/06/2058, LEX No 1725789.

42 Judgment of the Supreme Administrative Court of 14 December 2010, II GSK 1092/09, LEX No 835134. 
of the Public Finance Discipline Violation Liability Act, but also, e.g. under criminal law ${ }^{43}$ or - in case of employees appointed to the tender committee - labour law ${ }^{44}$.

The contracting authority, as an entity disposing public funds, is obliged to act in a manner that will deepen trust in state bodies and encourage the spending of public funds in an economical and purposeful manner. The implementation of these principles can only occur in cases of an action consistent with the letter of the generally applicable law, which allows for choosing the most advantageous tender in accordance with the principles of public procurement contract awards, as well as principles of public finance.

\section{Bibliography:}

Dębowska-Romanowska T., Prawo budżetowe państwa i samorzq̨u terytorialnego [in:] W. Wójtowicz (ed.), Prawo finansowe, C.H. Beck, Warszawa 1999.

Filipek M.. Dobór składu osobowego komisji przetargowej, „Zamówienia Publiczne Doradca” 2008, No 3, pp. 67-73.

Glumińska-Pawlic J., Komentarz do art. 61 u.s.g. [in:] B. Dolnicki (ed.), Ustawa o samorzq̨dzie gminnym. Komentarz. 11 wyd., LEX No 587718911.

Glumińska-Pawlic J., Komentarz do art. 61 u.s.p. [in:] B. Dolnicki. Ustawa o samorzqdzie powiatowym. Komentarz, 2 wyd., LEX No 587284497.

Glumińska-Pawlic J., Komentarz do art. 72 u.s.g. [in:] B. Dolnicki (ed.) Ustawa o samorzq̨dzie województwa. Komentarz, LEX No 587334845.

Iwaniec W., Kryteria pozacenowe - bieżqca praktyka-perspektywy, „Zamówienia Publiczne Doradca” 2019, No 3, pp. 11-18.

Iwaniec W., Odpowiedzialność za nieprawidłowości w procesie przygotowania i udzielania zamówienia, „Zamówienia Publiczne Doradca” 2015, No 10, pp. 6-11.

43 See Article 25 of PFDVLA. The most common crimes committed in connection with the unlawful application of provisions on public procurement include: venality of a public officer (Article 228 of PC), bribery (Article 229 of PC), paid protection (Article 230 and 230a of PC), abuse of public office (Article 231 of PC), forgery (Article 270 and 271 of PC), elimination of a document (Article 276 of PC).

44 See Articles 114-122 of LC, J.E. Nowicki, Zasada pisemności postępowania, „Zamówienia Publiczne Doradca” 2008, No 5, pp. 43-51. 
Jagiełło D., Kompetencje i zadania komisji przetargowej, „Zamówienia Publiczne Doradca” 2011, No 11, pp. 76-80.

Lipiec-Warzecha L., Komentarz do art. 17 [in:] L. Lipiec-Warzecha, Odpowiedzialność za naruszenie dyscypliny finansów publicznych. Komentarz, LEX No 587281187.

Ludziejewski M., Najczęstsze błędy przy organizacji pracy komisji przetargowej, „Zamawiający” 2013, No 1, pp. 16-18.

Meducki M., Komisja przetargowa, „Zamówienia Publiczne Doradca” 2017, No 12, pp. 68-71.

Nowicki J.E., Zasada pisemności postępowania, „Zamówienia Publiczne Doradca” 2008, No 5, pp. 43-51.

Padrak K., Komisja przetargowa, „Zamówienia Publiczne Doradca” 2007, No 11, pp. 28-33.

Pieróg J., Prawo zamówień publicznych. Komentarz, 11 wyd., C.H. Beck, Warszawa 2012.

Pruszkowski R., Przesłanki i praktyczne skutki naruszenia dyscypliny finansów publicznych w zamówieniach publicznych, „Zamówienia Publiczne Doradca” 2009, No 9, pp. 14-27.

Pruszkowski R., Zakres odpowiedzialności kierownika zamawiajq̨cego oraz innych osób uczestniczqcych w postępowaniu, cz. 1, „Zamówienia Publiczne Doradca” 2015, No 12, pp. 12-18.

Urząd Zamówień Publicznych, Kiedy zamawiający może „wyręczyć się” osobq trzeciq?? „Zamówienia Publiczne Doradca” 2006, No 7, pp. 30-31.

Winiarz M., Odpowiedzialność za udzielanie zamówień publicznych w podsektorze samorzqdowym, „Finanse Komunalne” 2007, No 9, pp. 32-45.

Winiarz M., Naruszenie zasady bezstronności w postępowaniu o udzielenie zamówienia publicznego jako naruszenie dyscypliny finansów publicznych, „Finanse Komunalne” 2015, No 10, pp. 54-63. 